\title{
KRITIK SOSIAL DALAM NOVEL ORANG-ORANG OETIMU KARYA FELIX K. NESI SERTA RELEVANSINYA SEBAGAI BAHAN AJAR DI SMA: TINJAUAN SOSIOLOGI SASTRA
}

\author{
Muhammad Sukma Aji ${ }^{1}$, Zainal Arifin ${ }^{2}$ \\ ${ }^{1}$ Pendidikan Bahasa dan Sastra Indonesia \\ Universitas Muhammdiyah Surakarta \\ 1․310170107@student.ums.ac.id \\ ${ }_{2}^{2}$ Pendidikan Bahasa dan Sastra Indonesia \\ Universitas Muhammadiyah Surakarta \\ 2za135@ums.ac.id
}

\begin{abstract}
$\underline{\text { Abstrak }}$
Penelitian ini bertujuan untuk (1) mengungkapkan masalah sosial yang dikritik dalam novel Orang-Orang Oetimu karya Felix K. Nesi. (2) memaparkan relevansi kritik sosial dalam novel Orang-orang Oetimu karya Felix K. Nesi sebagai bahan ajar sastra Indonesia di SMA. Penelitian menggunakan metode pendekatan kualitatif. Data dalam penelitian ini berupa satuan-satuan lingual seperti kalimat-kalimat, paragraf, maupun wacana yang mengandung kritik sosial pada novel. Teknik pengumpulan data pada penelitian ini menggunakan teknik pustaka, simak, dan catat. Validitas keabsahan data penelitian ini menggunakan teknik triangulasi teori. Teknik analisis data yaitu dengan melakukan pembacaan secara mendalam hingga diperoleh hasil penelitian. Hasil penelitian ini menunjukkan (1) Terdapat delapan masalah sosial yang dikritik dalam novel ini meliputi masalah politik, ekonomi, pendidikan, kebudayaan, moral, keluarga, agama, dan gender. (2) Hasil analisis novel Orang-orang Oetimu dapat direlevansikan ke dalam pembelajaran sastra Indonesia di SMA. Namun Novel Orang-orang Oetimu tidak sesuai dengan kriteria kelayakan bahan ajar yaitu dari segi bahasa, psikologi, dan latar belakang sosial budaya.
\end{abstract}

Kata Kunci: Kritik Sosial, Masalah Sosial, Sosiologi Sastra, Bahan Ajar

\begin{abstract}
This study aims to (1) reveal the social problems criticized in Felix K. Nesi's novel Orang-orang Oetimu. (2) explaining the relevance of social criticism in Felix K. Nesi's novel Orang-orang Oetimu as a teaching material for Indonesian literature in high school. The research uses qualitative approach methods. The data in this study are in the form of lingual units such as sentences, paragraphs, and discourses that contain social criticism in novels. Data collection techniques in this study use library techniques, check, and record. The validity of this research data using theory triangulation technique. Data analysis techniques are by conducting in-depth readings until the results of the research are obtained. The results of this study show (1) There are eight social issues criticized in the novel including political, economic, educational, cultural, moral, family, religious, and gender issues. (2) The results of the analysis of the novel Orang-orang Oetimu can be reflected into the learning of Indonesian literature in high school. But the Novel of Oetimu People does not fit the criteria for feasibility of teaching materials in terms of language, psychology, and socio-cultural background.
\end{abstract}

Keywords: Social Criticism, Social Issues, Sociology of Literature, Teaching Material 


\section{PENDAHULAUN}

Sastra merupakan ungkapan refleksi kehidupan sehari-hari manusia yang direpresentasikan ke dalam sebuah karya sastra oleh penciptanya yang berupa sastra lisan maupun tulis. Pada dasarnya, sastra merupakan sebuah sarana untuk menuangkan, pikiran, ide, serta pesan penulis. Karya sastra disampaikan menggunakan bahasa sebagai perantara yang ditujukan kepada masyarakat agar dapat mengambil nilai serta pembelajaran hidup. Lebih konkret Noor (2009:13) mengatakan karya sastra sebagai cerminan kehidupan tidak berarti karya sastra itu sendiri meskipun bersifat rekaan, tetapi tetap mengacu pada realitas dunia nyata. Dapat disimpulkan bahwa karya sastra adalah produk dari proses berpikir reflektif dan kreatif. Sementara itu, karya sastra terbagi ke dalam tiga genre yaitu drama, prosa, dan puisi.

Dari ketiga genre, peneliti menggunakan novel sebagai objek kajian penelitian. Novel termasuk dalam karya sastra prosa. Nurgiyantoro, (2009:10) mendeskripsikan novel sebagai sebuah karya prosa fiksi yang tidak terlalu panjang namun tidak terlalu pendek. Termasuk prosa fiksi, novel menjadi karya sastra yang paling populer karena memiliki daya tarik, menghibur, dan membuat pembaca merasa puas ketika menyelesaikan bacaannya. Oleh sebab itu, kehidupan sehari-hari manusia tidak terlepas dari objek pengembangan tema novel. Kehidupan manusia begitu kompleks terhadap permasalahan sosial menjadi cerminan bahan ide penulisan oleh pengarang.

Permasalahan sosial tidak akan pernah ada habisnya selama manusia ada dan menjalankan kehidupan. Masalah-masalah inilah yang menjadi bahan utama penulis/pengarang dalam membuat sebuah karya sastra. Untuk menciptakan sebuah karya sastra tentu melalui proses menulis sehingga dapat terbaca apa yang menjadi kegelisahan. Para penulis berangkat dari kegelisahannya melihat permasalahan sosial yang kemudian dituangkan dalam bahasa tulis agar khalayak dapat melihat realitas yang ada.

Tentunya penciptaan karya sastra yang berangkat dari permasalahan sosial ini tak jauh dari lingkungan di mana pengarang tinggal. Damono (2002:6) mengemukakan pendapat Grebstein yang menjelaskan bahwa karya sastra tidak dapat dipahami secara selengkap-lengkapnya apabila dipisahkan dari lingkungan, kebudayaan, atau peradaban yang menghasilkan. Pada umumnya permasalahan atau ketimpangan sosial ini seperti kemiskinan, pendidikan, kesehatan, ketidakadilan, dan masih banyak lagi. Sehingga dalam karya sastra khususnya novel, masalah-masalah di masyarakat dikemas dan menghadirkan kritik sosial.

Kritik hadir dalam novel sebagai pemantik pembaca agar tergugah hati nurani dalam menyikapi sistem yang dilakukan penguasa. Sejalan dengan ini Sawardi (1974:2) mengungkapkan kenyataan sosial yang ditampilkan oleh pengarang dalam karyanya dapat mengubah nilai-nilai kehidupan pembaca atau dalam fungsi ini, pengarang tidak menuliskan karyanya secara orisinal berdasarkan kehidupan aslinya namun membuat pengembangan cerita yang bersifat estetik dan imajiner. Kajian kritik sosial novel tentunya menggunakan pendekatan sosiologi sastra dalam menemukan hubungannya dengan masyarakat.

Penelitian yang dilakukan Ahmad Adib Abdullah (2014) memaparkan permasalahan sosial yang dikritik dalam kumpulan cerpen karya Puthut EA dalam tiga 
kategori aspek yang mendasari munculnya masalah tersebut. 1) masalah sosial-budaya, 2) masalah sosial-politik, dan 3) masalah sosial bidang ekonomi.

Novel yang menampilkan kritik-kritik terhadap permasalahan sosial yang mengangkat dari sisi etnografis ialah novel Orang-Orang Oetimu karya Felix K. Nesi. Novel karya Felix K. Nesi memiliki kelebihan pada karya yang dibuatnya dengan sisi pengungkapan runut kejadian secara sistematis, terarah, dan berpegang pada kronologis. Persoalan dan permasalahan kemanusiaan yang menjadi fokus dalam novel ini menjadi perhatian lebih Felix, sehingga peneliti tertarik untuk mengkaji masalah-masalah yang terdapat dalam novel dan mengembangkannya menjadi bahan ajar sastra di SMA.

Berdasarkan uraian di atas, fokus terdapat pada masalah yang terjadi dan bagaimana kritik terhadap permasalahan sosial yang diceritakan Felix melalui novelnya. Bagaimana permasalahan yang terjadi di Indonesia Timur sebagai bentuk sindiran tataran masyarakat akibat penjajahan yang terjadi kala itu. Ketidakharmonisan berjalan berdampingan dengan perkembangan zaman di pulau Jawa yang lebih maju. Lebih jauh fokus penelitian ini pada kritik terhadap HAM, ekonomi, pendidikan, dan kesejahteraan karena penjajahan.

Penelitian ini mendeksripsikan kritik sosial dalam novel Orang-orang Oetimu karya Felix K. Nesi dan relevansi kritik sosial dalam novel Orang-orang Oetimu karya Felix K. Nesi sebagai bahan ajar sastra Indonesia di SMA.

Hasil penelitian diharapkan dapat menambah kajian sastra khususnya pada sosiologi sastra serta tentang kritik sosial dalam karya sastra, yang ditampilkan dalam novel Orang-orang Oetimu karya Felix K. Nesi. Selain itu, dengan adanya penelitian ini diharapkan dapat menambah pengetahuan pembaca mengenai masalah sosial yang dikritik dan dibentuk penyampaian kritik melalui karya sastra dalam novel Orang-orang Oetimu.

\section{METODE}

Menurut Sugiyono (2013:2), metode penelitian secara garis besar merupakan cara ilmiah untuk mendapatkan data dengan tujuan dan kegunaan tertentu. Penelitian menggunakan metode pendekatan kualitatif. Objek dalam penelitian ini adalah kalimat yang berupa kritik sosial dalam novel Orang-orang Oetimu. Sedangkan subjek dari penelitian ini berupa latar belakang terjadinya kritik sosial dalam novel serta bagaimana bentuk kritik sosial yang ada dalam novel. Data dalam penelitian ini berupa satuan-satuan lingual seperti kalimat-kalimat, paragraf, maupun wacana yang mengandung kritik sosial pada novel. Sumber data terkait dengan teks yang terdapat dalam novel Orang-orang Oetimu. Sumber data terkait dengan teks yang terdapat dalam novel Orang-orang Oetimu karya Felix K. Nesi. Teknik pengumpulan data pada penelitian ini menggunakan teknik pustaka, simak, dan catat. Validitas keabsahan data penelitian ini menggunakan teknik triangulasi teori. Teknik analisis data yaitu dengan melakukan pembacaan secara mendalam hingga diperoleh hasil penelitian. 


\section{HASIL DAN PEMBAHASAN}

\section{A. Masalah yang Dikritik Felix K. Nesi dalam Novel Orang-orang Oetimu}

Analisis kritik sosial dalam novel Orang-orang Oetimu karya Felix K. Nesi dengan tinjauan sosiologi sastra menggunakan metode pendekatan deskriptif kualitatif ditemukan delapan aspek kehidupan yang dikritk.

Tabel 1. Kritik Sosial Novel Orang-orang Oetimu

\begin{tabular}{cll}
\hline No & Masalah Sosial yang Dikritik & Halaman \\
\hline 1. & Politik & $86,102,107$ \\
2. & Ekonomi & $108,137,153$ \\
3. & Pendidikan & 99,100 \\
4. & Kebudayaan & $167,18,189$ \\
5. & Moral & 102,124 \\
6. & Keluarga & 99,120, \\
7. & Agama & 91,130 \\
8. & Gender & $97,143,195$ \\
\hline
\end{tabular}

Lebih lanjut analisis pembahsan menganai kritik sosial disajaikan rinci sebagai berikut.

1) Kritik Sosial Masalah Politik

Masalah sosial bidang politik berkaitan dengan golongan orang-orang yang memiliki kekuasaan di suatu wilayah pada lembaga-lembaga tertentu. Masalah bidang politik ini meliputi kesewenang-wenangan pemerintah, ketimpangan sosial akibat kebijakan yang berlaku serta didasari kepentingan individu.

"Saya tidak tahu kalau ada polisi yang bisa melucu," kata perempuan itu. "Polisikan lebih suka memukul orang daripada membikin lucu." (O3, 2020: 86)

"Foto Muder Teresa yang sedang memeluk dan memberikan segepok uang kepada Silvy menjadi sangat viral, dimuat di koran-koran, ditayangkan di TVRI dan dideskripsikan baik oleh para penyiar radio. Di pemilihan umum berikutnya, Muder Teresa itu terpilih menjadi anggota legislatif, mengikuti suaminya." (O3, 2020: 10)

Kritik sosial masalah politik banyak sekali dimuat pada novel ini. Disimpulkan bahwa novel Orang-orang Oetimu cukup banyak mengkritik masalah politik karena menjadi dasar berbagai permasalahan yang ditimbulkan. Permasalah itu seperti kekerasan dari aparat penegak hukum, penggunaan uang untuk mencari suara rakyat, hingga pembuatan kebijakan yang menyusahkan masyarakat. Politik dijadikan kekuasaan yang kemudian digunakan berbuat menindas, mencurangi, dan menyusahkan masyarakat.

2) Kritik Sosial Masalah Ekonomi

Ekonomi dapat didefinisikan sebagai suatu usaha guna memenuhi kebutuhan sumber daya manusia yang berkaitan dengan produksi, distribusi, dan konsumsi. Setiap orang atau kepala keluarga wajib memenuhi nafkah dirinya dan atau keluarganya. Namun setiap orang memiliki kemampuan ekonomi 
masing-masing dan tak sedikit yang untuk memenuhi kebutuhan ekonomi mereka masih sangat kurang.

"Itu semua tidak akan terjadi hanya jika kau punya uang pelicin atau orang dalam. Sayang sekali Yunus tidak mempunyai dua hal itu." (O3, 2020: 108)

"Di dunia yang fana ini, uang bisa membeli kebahagiaan kalau kau tahu cara menggunakannya," kata seorang prajurit kepada Linus." (O3, 2020: 137)

Dari kutipan di atas kritik sosial masalah ekonomi ditujukan pada pemenuhan kebutuhan dengan uang. Uang menjadi segalanyanya dan membuat setiap orang mencari keuntungan dengan cara apapun untuk mendapatkan uang. Budaya korupsi sudah mendarah daging mulai dari orang biasa hingga para pejabat. Permasalahan ini sampai sekarang masih terjadi di kehidupan modern, ketika tuntutan ekonomi semangkin banyak.

3) Kritik Sosial Masalah Pendidikan

Pada dasarnya pendidikan adalah proses memanusiakan manusia agar beradab sesuai dengan norma yang berlaku di masyarakat. Pendidikan adalah hak setiap orang di Indonesia. Namun, pendidikan belum merata ke seluruh wilayah di negeri ini. Felix melalui novelnya mengkritik pemerintah yang tidak memperhatikan pihak sekolah dalam membuat kebijakan dan pengembangan pendidikan dengan kebutuhan peserta didiknya.

"Mereka harus menerima kenyataan, bahwa untuk menjadi cerdas mereka membutuhkan uang." (O3, 2020: 100)

"Sementara itu, setiap bulan, ada tiga sampai lima anak yang bunuh diri karena tidak lolos seleksi masuk ke sekolah itu-ada yang menggantung lehernya di kamar mandi, ada yang minum racun rumput, ada yang membakar diri dengan minyak tanah, ada juga yang melompat ke dasar jembatan Laliba." (O3, 2020: 99)

Kutipan di atas menjelaskan bahwa sekolah di pelosok negeri yang seharusnya dapat digunakan untuk menimba ilmu malah membuat anak-anak yang ada di Oetimu berhenti sekolah. Dari uraian tersebut dapat disimpulkan bahwa terdapat kritik terhadap pembangunan dan penetapan kebijakan pendidikan di sekolah yang masih jauh dalam memanusiakan manusia. Sistem pendidikan di Indonesia masih belum memberikan perubahan hal baik kepada masyarakat.

4) Kritik Sosial Masalah Kebudayaan

Kebudayaan adalah kehidupan masyarakat mulai dari sistem gagasan, tindakan, hasil karya manusia yang dijadikan milik bersama dengan belajar dan merealisasikannya. Setiap daerah memiliki kebudayaan masing-masing yang berkembang di masyarakat. Hal ini dipengaruhi unsur-unsur kebudayaan yaitu norma yang berlaku. Pada novel ini Felix menyampaikan kritikannya kepada media yang hanya memperlihatkan keindahan fisik wanita Indonesia yang ada di pulau Jawa. 
"Di masa itu, majalah dan televisi tak henti menunjukkan kecantikan perempuan-perempuan di tanah Jawa, sehingga perempuanperempuan Timor mulai risih kepada tubuhnya sendiri dan berpikir, untuk menjadi cantik, mereka harus menjadi seperti perempuan Jawa." (O3, 2020: 189)

Kutipan di atas menjelaskan akibat kerja media yang hanya terfokus di pulau Jawa sehingga mengabaikan bahwa Indonesia ini sangat beragam. Dalam hal ini Felix juga mengkritisi perilaku perempuan-perempuan yang berupaya menghilangkan identitas asli dan menjadi karakter orang lain.

5) Kritik Sosial Masalah Moral

Pada prinsipnya moral adalah ajaran atau aturan bertingkah laku baik dalam lingkungan bermasyarakat. Setiap manusia adalah makhluk sosial yang memiliki aturan bertingkah laku sesuai dengan norma yang berlaku. Dalam novel Orang-orang Oetimu dijumpai kritik masalah moral yang saat ini banyak terjadi seperti memamerkan harta yang dimiliki dengan kedok membantu orang lain. Kritik masalah moral seperti pada kutipan berikut.

"Ia memeluk anak kecil itu, lalu membuka tasnya dan memberikan sangat banyak uang kepada si anak, dengan gerak lambat yang cukup untuk bisa diabadikan oleh kamera wartawan." (O3, 2020: 102)

Dari kutipan di atas diketahui masalah moral yang terjadi antara lain sombong dengan apa yang dimiliki agar semua orang tahu dan kejujuran dalam bertindak. Sikap-sikap seperti itu seharusnya dihindari dalam kehidupan karena hanya akan menciptakan tatanan sosial yang tidak bermoral. Dalam kehidupan sosial manusia seharusnya menciptakan kerja sama yang baik dalam hal apapun sesuai norma yang berlaku.

6) Kritik Sosial Masalah Keluarga

Dalam keluarga sudah dipastikan antara anggota keluarga satu dengan yang lain memiliki interaksi. Dalam interaksi tersebut sering terjadi disorganisasi dalam masyarakat kecil yakni keluarga. Disorganisasi keluarga sering menimbulkan konflik antar anggotanya karena perbedaan cara pandang. Kritik sosial sering menyangkut ketidakharmonisan dalam keluarga agar manusia lebih sadar pentingnya menjaga hubungan antar keluarga. Konflik keluarga yang muncul pada novel ini yaitu terlalu mementingkan ego sendiri. Seperti pada kutipan berikut.

"Ayahnya suka kalap dan melemparkan barang-barang, tetapi ketika ibunya benar-benar pergi, ayahnya selalu memeluk periuk dan panci dan segala macam barang peninggalan ibunya-yang telah penyoksambil menangis." (O3, 2020: 120)

Dalam novel ini tidak banyak ditampilkan konflik masalah keluarga sehingga kritik yang disampaikan juga tidak terlalu banyak. Dilihat bahwa disorganisasi dalam keluarga terjadi karena kurangnya komunikasi antar anggota keluarga. Kritik pun lebih ditujukan kepada orang tua yang tidak memenuhi hakhak anak. 
7) Kritik Sosial Masalah Agama

Manusia merupakan makhluk yang bertuhan, hakikat penciptaan manusia pun adalah untuk menyembah dan taat kepada Tuhan. Dengan manusia menyembah dan taat kepada Tuhan maka mereka memiliki fondasi yang kuat (keimanan) untuk mematuhi perintah dan menjauhi larangan-Nya. Namun, keimanan antara umat berbeda sehingga jika lemah iman mereka senantiasa akan menyeleweng dari ajaran agama yang dianutnya. Seperti pada kutipan di bawah ini.

"Kadang kala pemilik warung sampai ketiduran menunggu mereka berdebat tentang paling apa yang paling cocok diminum sesudah makan rusuk babi, atau tentang mengapa Vatikan menumpuk begitu banyak kekayaan sementara orang-orang di berbagai negara mati kelaparan." (O3, 2020: 130)

Kutipan di atas memperlihatkan bahwa kritik agama disampaikan kepada negara terkecil di dunia sebagai kiblat agama di negara-neraga yang suka menumpuk kekayaan. Sementara orang-orang di berbagai negara banyak mati yang kelaparan. Kritik sosial masalah agama yang disampaikan Felix juga disampaikan untuk mengkritik pastoran di gereja.

8) Kritik Sosial Masalah Gender

Masalah gender berhubungan dengan stereotip antara peran dan kedudukan wanita di masyarakat dalam rangka kesetaraan gender. Hal ini menimbulkan ketidakadilan sosial antara kedudukan laki-laki dan perempuan. Ketidaksetaraan gender ini berdampak pada pengalaman hidup seseorang. Pada novel Orang-orang Oetimu kritik sosial ditujukan kepada subordinasi perempuan yang mana mereka dibatasi pada aktivitas tertentu. Seperti pada kutipan berikut ini.

"Tukang masak, apalagi hanya perempuan, tidak boleh mengetahui urusan penting begini." (O3, 2020: 195)

Dari cuplikan teks mengenai kritik sosial masalah gender dapat dilihat bahwa isu kesetaraan gender belum sepenuhnya disadari semua orang bahkan orang-orang yang berpendidikan maupun pemuka agama. Perempuan diposisikan sebagai orang yang tidak penting untuk mengisi jabatan-jabatan fungsional maupun struktural. Pandangan perempuan di bawah laki-laki ini dilanggengkan dengan budaya patriarki.

Berdasarkan analisis kritik sosial novel Orang-orang Oetimu karya Felix K. Nesi dapat disimpulkan bahwa kritik sosial didominasi masalah politik dan masalah moral. Secara garis besar kritik sosial dalam novel Orang-orang Oetimu meliputi masalah politik, ekonomi, pendidikan, kebudayaan, moral, keluarga, agama, dan gender. Dalam novel ini tidak ditemukan kritik terhadap masalah teknologi karena memang tidak ada pembahasan mengenai teknologi di dalam novel ini. Penelitian mengenai kritik sosial juga dilakukan oleh Retnasih (2014) meenemukan delapan aspek masalah sosial yang dikritik dalam Roman Momo karya Michael Ende. Perbedaan dengan hasil temuan yang dilakukan peneliti 
adalah tidak ada kritik terhadap masalah teknologi pada novel Orang-orang Oetimu.

\section{B. Relevansi Kritik Sosial dalam Novel Orang-orang Oetimu karya Felix K. Nesi}

Tujuan pendidikan nasional menurut Undang-undang No. 20 Tahun 2003 yaitu "pendidikan nasional adalah pendidikan yang berdasarkan Pancasila dan Undang-Undang Dasar Negara Republik Indonesia Tahun 1945 yang berakar pada nilai-nilai agama, kebudayaan nasional Indonesia dan tanggap terhadap tuntutan perubahan zaman." Bahasa Indonesia sebagai salah satu mata pelajaran di tingkat satuan pendidikan ikut serta mensukseskan tujuan pendidikan nasional tersebut. Salah satu upaya yang dilakukan untuk mencapai tujuan tersebut yaitu dengan pembelajaran kesusastraan.

Hasil analisis novel Orang-orang Oetimu dapat diimplikasikan ke dalam pembelajaran di SMA sebagai relevansi terhadap bahan ajar

1) Relevansi Hasil Penelitian dengan Kurikulum KTSP

Di dalam KTSP fungsi pengajaran sastra yakni meningkatkan kemampuan peserta didik agar mampu berkomunikasi dalam bahasa Indonesia dengan baik dan benar, baik secara lisan maupun tulis, serta menumbuhkan apresiasi terhadap karya sastra. Selain itu, dengan pengajaran sastra diharapkan dapat menambah wawasan kesusastraan, budi pekerti, serta kemampuan bersastra peserta didik. Di samping itu, pengajaran sastra menjadi sarana bagi pengembangan karakter peserta didik.

Karya sastra khususnya novel memiliki peran dalam KTSP yang disesuaikan dengan Standar Kompetensi dan Kompetensi Dasar dalam meningkatkan kemampuan bersastra. Hal ini dapat dilihat pada Standar Kompetensi dan Kompetensi Dasar tingkat SMA kelas XI semester I dan kelas XII semester I.

2) Relevansi Hasil Penelitian dengan Kurikulum 2013

Kurikulum 2013 merupakan pengembagan dari kurikulum 2006 (KTSP) yang dilandasi pemikiran tentang tantangan masa depan, persepsi masyarakat, perkembangan pengetahuan dan pedagogi, kompetensi masa depan, dan fenomena negatif yang mengemuka (Pedoman Pelatihan Implementasi Kurikulum 2013, 2013: 4). Kurikulum 2013 tidak hanya menitikberatkan pada kompetensi peserta didik melainkan juga sebagai pembentukan karakter.

Meskipun demikian, kurikulum 2013 tidak mempengaruhi tujuan pembelajaran sastra di sekolah. Jika dalam KTSP dikenal Standar Kompetensi dan Kompetensi Dasar, dalam Kurikulum 2013 digunakan istilah Kompetensi Inti dan Kompetensi Dasar (KI-KD). Pembelajaran sastra dengan kurikulum 2013 di sekolah adalah berbasis teks serta tidak lepas dari teori yang melatarbelakangi. Pembelajaran sastra termaktub dengan rinci di dalam Kurikulum 2013 melalui penjabaran KD pada KI 3 dan KI 4. KD 3 sebagai bentuk penjabaran KI 3.

3) Relevansi Hasil Penelitian sebagai Bahan Ajar di SMA

Bahan ajar merupakan salah satu faktor yang menentukan keberhasilan suatu kegiatan belajar mengajar dalam mencapai tujuan. Menurut Direktorat Pembinaan Sekolah Menengah Atas (2008:6), pengertian bahan ajar adalah segala 
bentuk bahan yang digunakan untuk membantu guru dalam melaksanakan kegiatan belajar mengajar. Disimpulkan bahwa, bahan ajar yang ditentukan untuk kegiatan pembelajaran hendaknya dipersiapkan agar menunjang tercapainya indikator, standar kompetensi, dan kompetensi dasar.

Penelitian mengenai kritik sosial dalam karya sastra dan relevansinya sebagai bahan ajar juga pernah dilakukan oleh Praptiwi (2014). Praptiwi menganalisis novel Surga Retak karya Syahmedi Dean dapat diimplikasikan ke dalam pembelajaran di SMA satuan pendidikan dengan Kurikulum Tingkat Satuan Pendidikan (KTSP) dan satuan pendidikan dengan Kurikulum 2013.

\section{a) Bahan Ajar Berupa Novel Orang-orang Oetimu}

Rahmanto (2004: 31) mengungkapkan mengenai tiga aspek penting yang tidak boleh dilupakan dalam melakukan pemilihan bahan ajar sastra, yaitu dari sudut bahasa, dari sudut psikologi (kematangan jiwa), dan dari sudut latar belakang kebudayaan peserta didik. Berdasarkan kriteria tersebut, maka penelitian dari novel Orang-orang Oetimu ini tidak layak digunakan sebagai bahan ajar sastra di SMA. Hal itu mengingat novel ini mencakup dua dari tiga kriteria yang disebutkan sebagai kelayakan bahan ajar sastra.

Pertama berdasarkan sudut bahasa novel ini sebenarnya menggunakan bahasa yang mudah dimengerti juga beberapa bahasa asing dan daerah dapat menambah kosakata bahasa siswa. Namun dari sudut psikologi (kematangan jiwa) novel ini memiliki batasan umur yakni di atas sembilan belas tahun. Sementara, usia peserta didik SMA kelas XI belum mencapai usia yang diperbolehkan membaca novel. Selain itu, dari sudut latar belakang peserta didik, setiap wilayah memiliki kebudayaan masing-masing sehingga apabila bahan ajar ini diterapkan di daerah yang memiliki latar belakang berbeda maka peserta didik akan kesulitan memahami cerita dalam karya sastra. Kelemahan lain selain kriteria adalah penggunaan bahan ajar yang berupa novel adalah tidak semua peserta didik memiliki novel Orang-orang Oetimu.

b) Analisis Kritik Sosial

Kritik sosial dalam masyarakat bertujuan atau berfungsi sebagai kontrol terhadap jalannya sebuah sistem sosial atau proses bermasyarakat. Kritik sosial mampu menjaga keseimbangan sistem sosial masyarakat melalui perantara karya sastra. Tindakan sosial maupun individual yang menyimpang dari nilai moral maupun sosial dapat ditinjau melalui kritik sosial.

Analisis kritik sosial dalam novel Orang-orang Oetimu dapat dijadikan sebagai bahan ajar di SMA. Salah satunya dengan mencari dan menemukan kritik yang terdapat dalam novel kemudian membandingkannya dengan fenomena di sekitar mereka. Selain itu, menganalisis kritik sosial dalam karya sastra dengan menggunakan pendekatan sosiologi sastra memudahkan peserta didik menangkap kritik yang disampaikan pengarang dalam karya sastranya. Peserta didik diajak lebih peka dan kritis melihat realitas yang ada di kehidupan masyarakat. Sementara itu, kelemahan bahan ajar berupa analisis kritik sosial dalam novel Orang-orang Oetimu dimungkinkan terjadinya kekurangpahaman peserta didik 
dalam membedakan kritik sosial antara masalah satu dengan masalah yang lain. Bahan ajar berupa analisis kritik sosial dan lembar kerja siswa terlampir pada lampiran 2.

\section{SIMPULAN}

Dalam penelitian ini terdapat keterbatasan di luar kendali peneliti, yang secara langsung maupun tidak langsung memengaruhi hasil penelitian. Banyak sekali kritik sosial yang secara implisit menjadi bias karena dapat dimasukan sebagai masalah sosial bidang lainnya. Hal ini mungkin akan berbeda sudut pandang dalam menemukan data yang berupa kalimat kritik sosial antar pembaca sekalian. Berdasarkan hasil analisis yang dilakukan terhadap novel Orang-orang Oetimu karya Felix K. Nesi, dapat disimpulkan meliputi empat hal sebagai berikut.

1) Terdapat delapan masalah kritik sosial novel ini meliputi masalah politik, ekonomi, pendidikan, kebudayaan, moral, keluarga, agama, dan gender. Kritik terhadap masalah politik dan moral yang paling banyak ditemukan dalam novel ini. Sementara itu, tidak ditemukan kritik terhadap masalah teknologi karena memang tidak ada pembahasan mengenai teknologi di dalam novel ini.

2) Hasil analisis novel Orang-orang Oetimu dapat direlevansikan ke dalam pembelajaran bahasa dan sastra Indonesia di SMA. a) Relevansi hasil temuan dapat digunakan oleh satuan pendidikan yang masih menerapkan kurikulum KTSP hingga Kurikulum 2013 pada SK-KD atau KI-KD sesuai yang dijelaskan dalam pembahasan. b) Relevansi novel Orang-orang Oetimu sebagai bahan ajar sastra yaitu berupa analisis kritik sosial yang terdapat dalam lampiran penelitian ini.

Penulis menyarankan agar peneliti dalam membaca atau menikmati karya sastra khususnya pada novel Orang-orang Oetimu hendaknya memahami sebuah karya sastra adalah sebagai karya yang utuh. Dengan memahami maksud yang terkandung dalam novel, mengetahui latar belakang pengarang dan sebagainya. Dengan menyelesaikan pembacaan terhadap karya sastra dapat menyimpulkan dan mengambil pelajaran berharga dari sebuah karya sastra. 


\section{DAFTAR PUSTAKA}

Abdullah, Ahmad Adib. 2014. Kritik Sosial dalam Kumpulan Cerpen 'Seekor Bebek Yang Mati di Pinggir Kali' Karya Puthut EA. Skripsi S1: FBS Universitas Negeri Yogyakarta.

Damono, Sapardi Djoko 2002. Sosiologi Sastra: Sebuah Pengantar Ringkas. Jakarta: Pusat Pengembangan Bahasa, Departemen Pendidikan dan Kebudayaan.

Khair, U., \& Misnawati, M. (2022). Indonesian language teaching in elementary school: Cooperative learning model explicit type instructions chronological technique of events on narrative writing skills from interview texts. Linguistics and Culture Review, 6, 172-184.

Misnawati, M., Poerwadi, P., \& Rosia, F. M. (2020). Struktur Dasar Sastra Lisan Deder. Pedagogik: Jurnal Pendidikan, 15(2), 44-55.

Noor, Redyanto. 2009. Pengantar Pengkajian Sastra. Semarang: Fasindo.

Nurgiyantoro, Burhan. 2009. Teori Pengkajian Fiksi. Yogyakarta: Gadjah Mada University Press.

Perdana, I., \& Misnawati, M. P. (2019). Cinta dan Bangga Berbahasa Indonesia Di Perguruan Tinggi. SPASI MEDIA.

Praptiwi, Rosita. 2014. Kritik Sosial dalam Novel 'Surga Retak Karya' Syahmedi Dean: Tinjauan Sosiologi Sastra dan Relevansinya sebagai Bahan Ajar Sastra Indonesia di SMA. Skripsi thesis, Universitas Muhammadiyah Surakarta.

Rahmanto, B. 2004. Metode Pengajaran Sastra. Yogyakarta: Kanisius.

Retnasih, Anisa Octafinda. 2014. Kritik Sosial dalam Roman Momo Karya Michael Ende (Analisis Sosiologi Sastra).

Sarwadi. 1974. Pengantar Kritik Sastra. Yogyakarta: FKSS IKIP Yogyakarta.

Undang-undang Nomor 20 tahun 2003 tentang Sistem Pendidikan Nasional.

Sugiyono. (2014). Metode Penelitian Kuantitatif, Kualitatif dan R\&D. Bandung: Alfabeta Bandung.

Wiyatmi. 2013. Sosiologi Sastra: Teori dan Kajian terhadap Sastra Indonesia. Yogyakarta: Kanwa Publisher. 